\title{
THE PROGNOSTIC SIGNIFICANCE OF NEONATAL CONVULSIONS
}

\author{
BY \\ JOYCE B. BURKE \\ From the Children's Hospital, Sheffield \\ (RECEIVED FOR PUBLICATION MARCH 19, 1954)
}

'The baby met with an unpleasant reception-a sound beating. He had entered the world without crying, nearly suffocated by the protracted delivery, so the midwife held him face downwards for some seconds and slapped him until he did cry. For on entering into this world one must cry.'

Luigi Pirandello (translated by A. and H. Mayne).

There are many causes of convulsions during the first few days of life. These include intracranial damage, anoxia, congenital malformations, tetany and infections. It is not always possible to determine the aetiology at the time in any particular case, but the prognosis is of great importance to all concerned. With this in view, the case histories of all infants recorded as having convulsions or muscular twitchings in the Jessop Hospital, Sheffield, over a five-year period have been studied. There were 46 cases out of a total of 8,679 deliveries $(0 \cdot 2 \%)$; 18 infants died during the first 13 days of life, 28 were discharged from hospital, and 27 have been followed up.

Table I shows relevant details of those infants who died. A post-mortem examination was made in 16 cases. Cerebral haemorrhage accounted for death in nine (Nos. 1-9). Anoxia was the cause of death in four (Nos. 10-13) and was present in the two infants on whom no post-mortem examination was

TABLE 1

RELEVANT DETAILS OF DEAD INFANTS

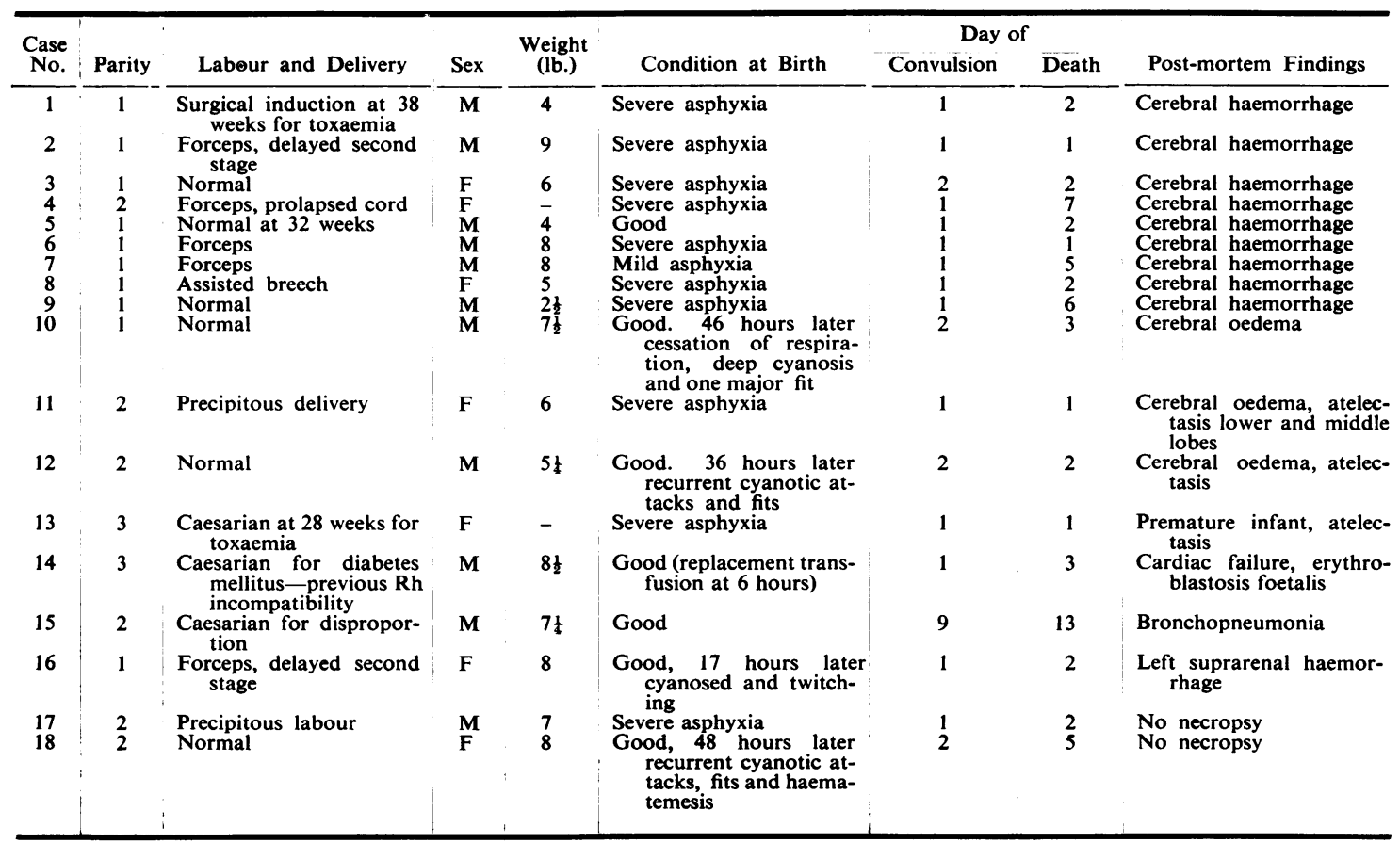


made. Six infants were under $5 \frac{1}{2} \mathrm{lb}$. in weight. It will be noted that convulsions occurred during the first two days of life in all but one of these infants.

Table 2 summarizes the case histories and followup notes on the 28 survivors. From the evidence presented, it will be seen that convulsions were associated with birth trauma or anoxia in 20 cases. In three infants (Nos. 33, 37, 38) delivery was normal and no cyanosis was noted at any time, and it was thus possible that the convulsions were a manifestation of tetany. However, in order to confirm this

TABLE 2

DETAILS OF SURVIVORS

\begin{tabular}{|c|c|c|c|c|c|c|c|}
\hline $\begin{array}{l}\text { Case } \\
\text { No. }\end{array}$ & Parity & Labour and Delivery & Sex & $\begin{array}{l}\text { Weight } \\
\text { (lb.) }\end{array}$ & Condition at Birth and Subsequently & $\begin{array}{l}\text { Day of Onset } \\
\text { of Convulsions }\end{array}$ & $\begin{array}{l}\text { Age and Con- } \\
\text { dition at Time } \\
\text { of Follow-up }\end{array}$ \\
\hline 19 & 1 & Forceps, delayed second stage & $\mathbf{M}$ & $7 \frac{1}{2}$ & $\begin{array}{l}\text { Cyanosed at birth; restless with } \\
\text { spasticity for } 36 \mathrm{hrs} \text {., one major fit }\end{array}$ & 2 & $2+$ yr., normal \\
\hline 20 & 1 & Precipitous & $\mathbf{M}$ & $7 \frac{1}{2}$ & $\begin{array}{l}\text { Cyanosis, head retraction, twitching } \\
\text { R. side for } 48 \mathrm{hrs} \text {. }\end{array}$ & 1 & $6 \mathrm{~m}$. , normal \\
\hline 21 & 1 & Normal, second stage $2 \frac{1}{2} \mathrm{hr}$. & $\mathbf{F}$ & $6 \frac{1}{2}$ & $\begin{array}{l}\text { Asphyxia pallida, twitching face and } \\
\mathrm{L} \text {. arm } 1 \mathrm{hr} \text {. later, satisfactory by } \\
36 \mathrm{hr} \text {. }\end{array}$ & 1 & $6 \mathrm{~m}$. , normal \\
\hline 22 & 1 & Normal & $\mathbf{M}$ & 7 & $\begin{array}{l}\text { Immediate asphyxia, intermittent } \\
\text { clonic fits } R \text {. side for } 36 \mathrm{hr} \text {. }\end{array}$ & 1 & 2 yr., normal \\
\hline 23 & 1 & Normal at 34 wk. & $\mathbf{M}$ & 5 & $\begin{array}{l}\text { Satisfactory at birth, recurrent cyano- } \\
\text { sis and twitching } 8 \mathrm{hr} \text {. later for } \\
48 \mathrm{hr} \text {. }\end{array}$ & 1 & $6 \mathrm{~m} .$, normal \\
\hline 24 & 1 & Normal & $\mathbf{M}$ & 61 & $\begin{array}{l}\text { Restless, high-pitched cry and } \\
\text { generalized twitching } 3 \mathrm{hr} \text {. after } \\
\text { birth; satisfactory by } 3 \mathrm{rd} \text { day }\end{array}$ & 1 & $4 \frac{1}{2}$ yr., normal \\
\hline 25 & 3 & Forceps for foetal distress & $\mathbf{M}$ & 9 & $\begin{array}{l}\text { Satisfactory at birth, recurrent twitch- } \\
\text { ing of limbs from 3rd to } 7 \text { th day }\end{array}$ & 3 & 31 yr., normal \\
\hline 26 & 1 & Normal, occipito-posterior & $\mathbf{M}$ & $7 \frac{1}{2}$ & $\begin{array}{l}\text { Immediate asphyxia, recurrent twitch- } \\
\text { ing for } 48 \mathrm{hr} \text {. }\end{array}$ & 1 & 3 yr., normal \\
\hline 27 & 5 & Forceps, obstructed labour & $\mathbf{M}$ & 9 & $\begin{array}{l}\text { Satisfactory at birth, cyanotic attacks } \\
\text { with twitching } R \text {. side 3rd to } \\
\text { 6th day }\end{array}$ & 3 & 4 yr., normal \\
\hline 28 & 1 & Normal & $\mathbf{M}$ & 8 & $\begin{array}{c}\text { Immediate } \\
\text { generalized twitching on 3rd day }\end{array}$ & 3 & 2 yr., normal \\
\hline 29 & 2 & Precipitous & $\mathbf{F}$ & $7 \frac{1}{2}$ & $\begin{array}{l}\text { Immediate mild asphyxia, 3rd to } 7 \text { th } \\
\text { day restless with generalized } \\
\text { twitching }\end{array}$ & 3 & $4 \frac{1}{2}$ yr., normal \\
\hline 30 & 3 & Precipitous & $\mathbf{M}$ & 61 & $\begin{array}{l}\text { Immediate asphyxia, major fit at } \\
3 \mathrm{hr} \text {. and again on } 3 \mathrm{rd} \text { day }\end{array}$ & 1 & $2 \frac{1}{2}$ yr., normal \\
\hline 31 & 2 & Forceps, breech & $\mathbf{M}$ & $9 t$ & $\begin{array}{l}\text { Immediate asphyxia, twitching } R \text {. } \\
\text { side for } 2 \text { days }\end{array}$ & 1 & $2 \frac{1}{2}$ yr., normal \\
\hline 32 & 1 & Normal & $\mathbf{M}$ & 5 & $\begin{array}{l}\text { Immediate asphyxia pallida, fits } 5 \text { th } \\
\text { and 6th days }\end{array}$ & 5 & $6 \mathrm{~m} .$, normal \\
\hline 33 & 1 & Normal, 31 wk. & $\mathbf{F}$ & $3 \frac{1}{2}$ & $\begin{array}{l}\text { Satisfactory at birth, twitching } R \text {. leg } \\
\text { 3rd and 4th days }\end{array}$ & 3 & $2 \frac{1}{2}$ yr., normal \\
\hline 34 & 1 & Breech & $\mathbf{M}$ & $6 \frac{1}{2}$ & $\begin{array}{l}\text { Immediate asphyxia, head retraction } \\
\text { and generalized twitching for } \\
24 \mathrm{hr} \text {. }\end{array}$ & 1 & 4 yr., normal \\
\hline $\begin{array}{l}35 \\
36 \\
37\end{array}$ & $\begin{array}{l}1 \\
2 \\
1\end{array}$ & $\begin{array}{l}\text { Caesarian for placenta praevia } \\
\text { Caesarian for obstructed labour } \\
\text { Normal }\end{array}$ & $\begin{array}{l}\mathbf{M} \\
\mathbf{M} \\
\mathbf{F}\end{array}$ & $\begin{array}{l}7 \\
8 \\
61\end{array}$ & $\begin{array}{l}\text { Immediate asphyxia, fits for } 2 \mathrm{hr} \text {. } \\
\text { Irritable and twitching for } 24 \mathrm{hr} \text {. } \\
\text { Satisfactory at birth, } 2 \text { major fits } 4 \text { th } \\
\text { day }\end{array}$ & $\begin{array}{l}1 \\
1 \\
4\end{array}$ & $\begin{array}{l}13 \mathrm{~m} ., \text { normal } \\
11 \mathrm{~m} ., \text { normal } \\
3 \frac{1}{2} \mathrm{yr} ., \text { normal }\end{array}$ \\
\hline 38 & 1 & Normal & $\mathbf{F}$ & $6 \frac{1}{2}$ & $\begin{array}{l}\text { Satisfactory at birth, } 2 \text { major fits } 5 \text { th } \\
\text { day }\end{array}$ & 5 & $2 \frac{1}{2}$ yr., normal \\
\hline 39 & 2 & Normal & $\mathbf{F}$ & 8 & $\begin{array}{l}\text { Satisfactory at birth, fits 2nd to } 7 \text { th } \\
\text { days, C.S.F. heavily blood- } \\
\text { stained }\end{array}$ & 2 & $3 \frac{1}{2} \begin{array}{c}\text { yr., normal } \\
\text { (initial delay) }\end{array}$ \\
\hline 40 & 1 & Forceps, delayed second stage & $\mathbf{M}$ & $7 \frac{1}{2}$ & $\begin{array}{l}\text { Immediate asphyxia, irritable, spastic, } \\
\text { bulging fontanelle } 48 \text { hr. after } \\
\text { birth, C.S.F. heavily blood- } \\
\text { stained, } 1 \text { R.-sided fit }\end{array}$ & 3 & $\begin{array}{l}4 \text { yr., blind L. } \\
\text { eye, otherwise } \\
\text { normal }\end{array}$ \\
\hline 41 & 3 & Precipitous ( $\$$ hr.) & $\mathbf{M}$ & $6 \frac{1}{2}$ & $\begin{array}{l}\text { Immediate asphyxia, head retraction } \\
\text { and spasticity for } 5 \text { days, several } \\
\text { major fits }\end{array}$ & 1 & $\begin{array}{l}\text { yr., spastic } \\
\text { quadriplegia, } \\
\text { severe mental } \\
\text { retardation }\end{array}$ \\
\hline 42 & 1 & Normal & $\mathbf{M}$ & 81 & $\begin{array}{l}\text { Satisfactory at birth, major fits } 4 \text { th } \\
\text { to } 7 \text { th days }\end{array}$ & 4 & $\begin{array}{l}2 \frac{1}{2} \text { yr., epilepsy } \\
\text { and mental } \\
\text { retardation }\end{array}$ \\
\hline 43 & 1 & Normal & $\mathbf{F}$ & 6 & $\begin{array}{l}\text { Satisfactory at birth, } 2 \text { severe cyanotic } \\
\text { attacks } 2 \text { nd day, major fit 3rd day }\end{array}$ & 3 & $\begin{array}{l}2 \frac{1}{2} \underset{\text { yr., severe }}{\text { mental re- }} \\
\text { tardation }\end{array}$ \\
\hline 44 & 1 & Normal & $\mathbf{M}$ & 7 & $\begin{array}{l}\text { Immediate mild asphyxia, } 2 \text { cyanotic } \\
\text { attacks and one fit on } 3 \text { rd day }\end{array}$ & 3 & $4 \underset{\text { yr., mental }}{\text { retardation }}$ \\
\hline 45 & 1 & Normal, mild toxaemia & $\mathbf{M}$ & 4 & Immediate asphyxia, fits for 5 days & 2 & $\begin{array}{l}3 \frac{1}{2} \\
\text { mental severe } \\
\text { tardation }\end{array}$ \\
\hline 46 & 1 & Forceps & $\mathbf{M}$ & $8 \frac{1}{2}$ & $\begin{array}{l}\text { Hydrocephalus and spina bifida, } \\
\text { recurrent fits from } 15 \text { th day }\end{array}$ & 15 & Not followed \\
\hline
\end{tabular}


diagnosis, serum calcium and phosphorus levels must be estimated, and this was not done in any of these cases. One infant was born with hydrocephalus and spina bifida, and was not followed up.

\section{Follow-up Study}

Twenty-seven infants were followed up, and all were over 6 months of age when last seen. The mother was questioned as to the milestones of development described by Gesell (1947), and a full clinical examination was made. In infants under 1 year of age special attention was paid to head control, general alertness and awareness of surroundings, ability to use the hands, maturity of grasp, and progress in locomotion and speech. In older children enquiry was made into the child's ability to carry out tasks such as feeding and dressing himself. During the interview he was encouraged to talk and name objects pointed out to him.

Further details of those children showing sequelae, temporary or permanent, are given below:

Case 39. Second pregnancy, normal delivery, birth weight $8 \mathrm{lb}$. (first child died shortly after birth); 34 hours after birth, onset of cyanosis and twitching, followed by generalized convulsions. Cerebrospinal fluid heavily blood-stained; subdural taps negative; bulging fontanelle, recurrent major convulsions and vomiting for seven days, with gradual improvement thereafter.

At 9 weeks old, smiling for two weeks, and following with eyes.

At 11 weeks, very poor head control in all positions.

At 18 weeks, severe head lag. In prone position can only just lift head off couch.

At 24 weeks, alert infant, interested in surroundings, laughing and cooing, very little head lag (general head level 3 months), kicks well.

At 7 months, practically no head lag. Transfers objects from one hand to the other.

At 8 months, sits alone without support.

At 10 months, pulling herself up to standing position.

At 13 months, walks alone.

At 26 months, spoke sentences from 21 months. Dry by night and day from 16 months. Feeding herself and managing a cup by 16 months. Running about at speed.

At $3 \frac{1}{2}$ years, alert child. Answers questions sensibly. Head circumference 20.6 in. No clinical abnormality detected.

Case 40. First pregnancy, surgical induction of labour with forceps delivery two days later, birth weight $7 \frac{1}{2} \mathrm{lb}$.; infant inhaled foul liquor at birth; febrile, spastic and irritable for six days; twitching of right side observed on third day; cerebrospinal fluid heavily blood-stained.

At 4 months, developing normally. Left internal strabismus noted.

At 11 months, thought to be blind in left eye.

At 4 years, milestones normal. Active and intelligent child, knows his letters. Blind in left eye-primary optic atrophy-no other abnormality.

Case 41. Third pregnancy (first child, forceps delivery, died at 8 days with convulsions. second child normal). Duration of labour three-quarters of an hour. Precipitous delivery at home. Birth weight $6 \frac{1}{2} \mathrm{lb}$. Cyanosed and cold on arrival at hospital within an hour of birth. Three hours later one major convulsion, followed by head retraction and spasticity for five days, Further generalized convulsions on fifth day. Subdural taps negative. Cerebrospinal fluid not examined. Condition satisfactory at time of discharge from hospital on eleventh day.

When examined at $2 \frac{1}{2}$ years, it was stated that he had smiled at 9 months, he was fed entirely by spoon, was unable to chew solids, and was incontinent of urine and faeces. He had had no further convulsions. Weight was $18 \mathrm{lb}$, head circumference $17 \mathrm{in}$. He had severe spastic quadriplegia, showed no interest in his surroundings and did not go for objects. He was unable to sit, even with support. He showed coarse ocular movements, right internal strabismus, and optic atrophy of the left eye.

Case 42. First pregnancy. Normal labour and delivery. Birth weight $8 \frac{1}{4} \mathrm{lb}$. Condition at birth satisfactory. Cephalhaematoma left parietal region. Recurrent major convulsions fourth to seventh days. Subdural taps were negative, and the cerebrospinal fluid not examined.

At 5 weeks, condition satisfactory. Cephalhaematoma still present.

At 8 months, unable to sit alone or grasp objects. Takes no interest in surroundings, Said to be having three to four convulsions daily for past three months.

At 16 months, crawls and stands without support. Chews biscuits. No words yet spoken. Several attacks of petit mal seen, and anticonvulsant therapy started.

At $2 \frac{1}{2}$ years, very restless-on the go all the time. Single words only. Unable to feed himself. Incontinent of urine. No major convulsion for a year, but occasional petit mal. On examination, extremely irritable and hyper-kinetic, almost unmanageable. No other clinical abnormality detected.

Case 43. First pregnancy. Normal labour and delivery. Birth weight $6 \mathrm{lb}$. Condition at birth satisfactory. Two severe cyanotic attacks on second day and a major fit on third day. Subdural taps negative. Cerebrospinal fluid normal. Discharged home on twenty-sixth day.

At 28 months, sat without help at 9 months. Unable to stand or creep. No words. Not feeding herself. No sphincter control. On examination, vacant expression, meaningles; kicks, little interest in surroundings. No abnormality found in nervous system. Severe mental defect obviously present.

Case 44. First pregnancy. Normal labour and delivery. Birth weight $7 \mathrm{lb}$. Mild asphyxia at birth. 
Condition appeared satisfactory until third day, when infant had two cyanotic attacks and a left-sided convulsion. He appeared normal the following day.

At 9 months, making no attempt to sit or go for objects. No interest in food until 8 months old. On examination, marked head lag in all positions.

At $9 \frac{1}{2}$ months, onset of major convulsions, partially controlled by phenobarbitone.

At 14 months, cannot sit alone or grasp objects.

At 4 years, walked alone at 2 years. Says a few words. Does not feed or dress himself. On examination fitlooking child. Head circumference 19 in. Speech very slow. Able to point to objects named. No abnormality found in nervous system. Fairly severe mental defect present.

Case 45. First pregnancy complicated by mild toxaemia. Normal delivery at 37 weeks. Birth weight $4 \mathrm{lb}$. Asphyxiated at birth. Marked rib recession for six hours. Fever, cyanotic attacks, twitching and spasticity for five days. Discharged home on twentyeighth day.

At 1 year, going for objects with hand for one month. Chewing for two months. On examination, full head control. No abnormality found in the central nervous system.

At 15 months, on examination unable to sit alone. Will not take weight on legs. No words. Obviously mentally retarded.

At 3 years, walked alone at 22 months, now running about. Saying single words. Unable to point out objects in picture book. No abnormality found in central nervous system.

Five children were severely mentally retarded (Nos. 41-45) and this was obvious by the age of a year in every case. Two of these children had had further convulsions. A sixth child was blind in the left eye and had primary optic atrophy. One child had spastic quadriplegia, apparently severe mental defect and probable blindness. Case 39 showed considerable delay in head control for 7 months; indeed, at 11 weeks an experienced observer thought that cerebral palsy with normal mentality might account for this. By the age of a year she was developing normally, and evidently fits into the category of so-called 'slow starters'.
Discussion

In this study convulsions (or muscular twitchings) occurring in the newborn period were associated with birth trauma, asphyxia or cyanotic attacks in 35 cases out of a total of 48 . The mortality rate from all causes was $38 \%$. Craig (1950) followed up 593 infants who showed evidence of intracranial irritation shortly after birth; 52 had some disability, and 38 of these were noted to have had muscular twitchings or convulsions during the first few days of life. Fleming and Morton (1930) in a review of 103 cases of intracranial haemorrhage state that convulsions were present in 51 patients and 17 of these died.

It is clear from the present series that convulsions and muscular twitchings are of serious significance in the newborn period. The immediate prognosis should be guarded. If the infant survives the first few days of life the ultimate prognosis appears to be relatively good, but progress should be watched closely for at least a year to ensure that development is proceeding normally. It is impossible to predict whether there will be subsequent mental or physical defect from the severity or nature of the initial symptoms.

\section{Summary}

The purpose of this study was to determine the prognostic significance of neonatal convulsions.

There were 48 cases in 8,679 deliveries $(0 \cdot 2 \%)$.

Eighteen infants $(37 \cdot 5 \%)$ died within a few days of birth.

One infant was born with hydrocephalus and spina bifida. The remaining 27 infants were followed up: five were severely retarded mentally, spastic quadriplegia was present in one of these, and further convulsions had occurred in two; a sixth child was blind in the left eye.

Convulsions were associated with birth trauma or anoxia in 35 cases $(70 \%)$.

I wish to thank Professor Illingworth, who suggested this investigation and gave much valuable advice, and Dr. T. Colver, for permission to use his cases.

REFERENCES

Craig, W. S. (1950). Archives of Disease in Childhood, 25, 325. Fleming, G. B. and Morton, E. D. (1930). Ibid., 5, 361.

Gesell, A. and Amatruda, C. S. (1947). Developmental Diagnosis. New York. 